\title{
SUSTAVNA PRAĆENJA KONVERZIJE SADNICAMA HRASTA LUŽNJAKA (Quercus robur L.) I KITNJAKA (Quercus petraea L.) S OBZIROM NA RAZLIČIT NAČIN SADNJE
}

\section{SYSTEMATIC MONITORING OF THE CONVERSION OF PEDUNCULATE OAK (Quercus robur L.) AND SESSILE OAK (Quercus petraea L.) SEEDLINGS WITH REGARD TO DIFFERENT PLANTING METHODS}

\author{
Miroslav BENKO'
}

\begin{abstract}
SAŽETAK
Istraživanja su obavljena u nizinskom dijelu Varaždinske županije, u šumi posebne namjene „FOPER“, g. j. „Zelendvor odsjek 13c na oko $3 \mathrm{~km}$ udaljenosti od rijeke Drave na nadmorskoj visini od $190 \mathrm{~m}$, u području gdje su sađene pretežito kulture smreke, borovca i bagrema iako je stanište pogodno za sadnju i uzgoj hrasta. S obzirom na promijenjene ekološke i klimatološke prilike osnovana je 2012. godine trajna pokusna ploha veličine 2,00 ha. Na plohi su posađene trogodišnje $(2+1)$ sadnice hrasta lužnjaka (Quercus robur L.) i hrasta kitnjaka (Quercus petraea L.) i to na dva načina. Jedan dio u razmaku sadnje 3 x 3 m u polipropilenskim štitnicima. Drugi dio razmaka sadnje 2 x $2 \mathrm{~m}$ uobičajenim načinom (bez štitnika). Cijela je površina podijeljena na 24 pod plohe približnih površina. Na jednoj plohi nalazi se jedna vrsta drveća. Raspored vrsta je naizmjeničan od plohe do plohe. Upotrijebljen je randomizirani oblik metode, sa 4 bloka i 3 ponavljanja. Visine biljaka mjerene su 5 godina uzastopce za vrijeme mirovanja vegetacije. Prsni promjeri mjereni su na kraju promatranog razdoblja kada su biljke bile više od 1,30 m. Učešće i intenzitet pepelnice utvrđivan je tri godine tijekom ljetnih mjeseci. Cilj istraživanja je proučavanje rasta i razvoja sadnica hrasta lužnjaka i hrasta kitnjaka na prostoru gdje do sada nije bilo uobičajeno saditi navedene vrste, iako za to postoje ekološko gospodarski uvjeti. Istraživanja ukazuju kako je broj biljaka nakon 5 godina izmjere smanjen je za $14 \%$. Kod hrasta lužnjaka smanjen je za 4 do 8\%, a kod hrasta kitnjaka za 17 do 22\%. Visine i prsni promjeri stabala u štitnicima značajno su veći bez obzira na vrstu drveća. Visine i prsni promjeri hrasta lužnjaka značajno su veće od hrasta kitnjaka. Nije utvrđena povezanost između visina stabala i prisutnosti pepelnice.
\end{abstract}

KLJUČNE RIJEČI: konverzija, rast, polipropilenski štitnici, visina stabalaca, FOPER šuma, Zelendvor, hrast lužnjak, hrast kitnjak

\section{UVOD}

\section{INTRODUCTION}

Recentne i sve učestalije klimatske promjene s izraženim ekstremnim pojavama aktualizirali su potrebu više integralnom i adaptiranom pristupu gospodarenja šumskim ekosustavima. Kvalitetniji pristupi, uz već poznate mjere zaštite, povećavaju potrebu novih, modernijih metoda sanacije, a ponajprije prevencije sastojina zahvaćene raznim gradacijama sekundarnih biotičkih čimbenika koji dodatno povećavaju, čak i premašuju primarne štete abiotičke naravi. Traženje modernih šumsko-uzgojnih koncepata po svojoj složenosti, skupoći, ali i snažnom djelovanju negativnih pri- 
tisaka, zahtijeva ispravno planiranje, što obuhvaća pravilan odabir vrsta, provenijencija, omjera smjese te kvalitetnog šumskoga reprodukcijskog materijala, ključnog za uspjeh predviđenoga zahvata. Ako k tome, pridodamo i općeprihvaćenu krilaticu, temeljni postulat hrvatskoga šumarstva, potrajnost gospodarenja, modernim rječnikom nazvano održivo gospodarenje, jasno je kako postupci na tom tragu zahtijevaju interdisciplinarnost. U konačnici cilj nam je osnovati što otpornije i prilagodljivije sastojine koje imaju sposobnost brže prilagodbe na novonastale promjene, a adaptirani šumsko uzgojni principi zasnovani su na suvremenim znanstvenim spoznajama.

Dosadašnja praksa, uvedena šezdesetih godina prošloga stoljeća preferirala je sadnju alohtonih vrsta drveća u obliku kultura i plantaža. Tijekom vremena, nakon svoje prvotne uloge, takve sastojine, uglavnom bez provođenja pravilnih i pravovremenih mjera njege sastojine (prije svega prorjeda) zahtijevaju promjene u načinu gospodarenja. Također, zbog svoje strukture šumske kulture su izrazito osjetljive na biotske i abiotske čimbenike.

U trenutku ispunjenja svoje primarne svrhe (zaštita i priprema staništa za pridolazak autohtonih vrsta drveća) potrebno je provesti njihovu konverziju u mješovite šume autohtonih vrsta drveća. Isto je poželjno i zbog činjenice da su mješovite šume upravo zbog svoje strukture puno otpornije na utjecaje biotskih i abiotskih čimbenika od šumskih kultura te imaju veću biološku raznolikost, što pridonosi boljem ispunjavanju općekorisnih funkcija. Također, će se povećanjem okolišne vrijednosti šuma i šumskih kultura postići i zaštita tala, voda i zraka, pridonijet će se ublažavanju učinaka klimatskih promjena na šume, zaštiti biološke raznolikosti, spremanju ugljika i proizvodnji kisika. Dugoročno će se unaprijediti i estetska uloga šuma te krajobrazna raznolikost, što će zajedno doprinijeti uvećanju okolišne vrijednosti te gospodarske vrijednosti resursa. $\mathrm{Na}$ vedeno nas upućuje da je takve sastojine potrebno šumsko uzgojnim radovima što prije obnoviti, odnosno prevesti u viši uzgojni oblik kako bi se doprinijelo povećanju njihove otpornosti i okolišne vrijednosti, povećanju općekorisnih funkcija i povećanju biološke raznolikosti. Problematika je zadnjih nekoliko godina aktualizirana mjerama iz Programa ruralnog razvoja Republike Hrvatske (razdoblje 2014. - 2020.), odnosno provođenjem tipa operacije 8.5.1 „Konverzija degradiranih šumskih sastojina i šumskih kultura". Realizacija istoga je u praksi obavljena metodom direktnih konverzija (sadnjom/sjetvom).

Konverzija (lat. conversio - pretvaranje) je uzgojni postupak kojim se vrši prevođenje jednog uzgojnog oblika šume u drugi, primjenom odgovarajućih uzgojnih mjera. Primjenjuju se dvije metode, indirektna i direktna. Indirektna konverzija označava korištenje postojećih stabala ili izbojaka, kod kojih se mjerama njege, koristeći biološki poten- cijal sastojine stvaraju uvjeti za prirodnu obnovu i prevođenje u viši uzgojni oblik. Direktna konverzija se obavlja sjetvom ili sadnjom istom ili drugim ekonomski vrijednim vrstama drveća, kada biološki potencijal sastojine ne osigurava uspjeh određenih gospodarskih mjera (uzgojnih) u stvaranju preduvjeta za prirodnu obnovu. Ako konverziju obavljamo istom vrstom drveća radi se o rekonstrukciji (npr. nakon prevođenja bukove panjače, sadimo/sijemo bukvu), ili ako mijenjamo neku drugu autohtonu vrstu drveća radi se o supstituciji (npr. nakon panjače bagrema sadimo/ sijemo hrast). Dugotrajan je to i kompleksan proces koji se jedino može ubrzati intenzivnim šumsko uzgojnim postupcima. Dugogodišnja sustavna istraživanja metodama indirektne konverzije, povođenjem principa oplodnih sječa i njihovim prevođenjem u visoki uzgojni oblik, s naglaskom na istraživanja našega priobalja, u panjačama hrasta crnike nalazimo u radovima Dubravca i Krejčija (2001), Krejčija i Dubravca $(2000,2004)$, Dubravca i Dekanića (2011), Dubravca i dr. (2018).

Nastavno na navedeno, Rješenjem Ministarstva poljoprivrede od 2. veljače 2012. godine u šumariji Varaždin, Uprave šuma Podružnica Koprivnica, unutar GJ "Zelendvor", dva su odsjeka 13c i 13d proglašena Šumom posebne namjene za znanstvena istraživanja, što je rezultiralo osnivanjem "FOPER" šume (Benko i dr. 2012, 2013). U proteklih nekoliko desetljeća došlo je do značajnijih promjena u okolišu s naslova vodnog režima. S jedne strane gradnja velikih hidro energetskih sustava s akumulacijskim jezerima, a s druge klimatske promjene koje se odražavaju kroz značajno povećanje temperature zraka. To nas je navelo na potrebitost provođenja ovakvih istraživanja u kojima se testiraju dvije vrste hrasta (lužnjak i kitnjak), kao i dva različita načina sadnje u polipropilenskim štitnicima (s manjim brojem biljaka - $1.111 \mathrm{kom} / \mathrm{ha}$ ) i bez štitnika (veći broj biljaka $-2.500 \mathrm{kom} / \mathrm{ha}$ ).

Cilj istraživanja je ispitivanje uspješnosti konverzije sadnjom dvije različite vrste hrasta (lužnjaka i kitnjaka) sađena na dva načina sadnje, jedan sadnjom sadnica u polipropilenskim štitnicima i drugi klasičnom sadnjom (bez štitnika).

Mayhead i Boothman (1997) su proučavali rast i razvoj dvogodišnjih sadnica hrasta kitnjaka tretirajući ih tijekom tri godine štitnicima različitih visina. Zaključili su da viši štitnici proizvode više biljke, ali nakon što biljka izađe iz štitnika njezin prirast se izjednačuje. Što su biljke više promjeri su im manji. Preživljavanje je bolje u štitnicima (Potter 1991, Ponder 1996), a i zaštita od divljači je bolja. Nakon 5 - godišnjeg rasta biljaka u štitnicima (Potter 1991) biljke su dovoljno stabilne i čvrste da mogu dalje same rasti bez pomoći štitnika, nakon njihovog uklanjanja. Preživljavanje biljaka je značajno veće u štitnicima (Liović i dr. 2019) nego bez njih. Biljke su u štitnicima puno više (čak tri puta), a i 
brže rastu te je ujedno smanjen utjecaj pepelnice (Liović 1991, 1993, 1996). Polipropilenski štitnici uspjeli su smanjiti mortalitet i povećati visinski prirast sadnica hrasta (Liović 2001). Sadnice u štitnicima imaju veći visinski prirast od sadnica bez štitnika (Kirinčić 2016).

\section{MATERIJAL I METODE MATERIAL AND METHODS}

\section{Područje istraživanja - Research area}

Šuma posebnom namjenom «FOPER šuma» sastavni je dio gospodarske jedinice "Zelendvor" kojom gospodari Šumarija Varaždin i prostire se na površini od 3,64 ha. "FOPER šuma" se sastoji od dva dijela, istraživački i memorijalni dio.

Istraživački dio nalazi se u odsjeku $13 \mathrm{c}$ na površini od 2 ha u kojemu je posađeno 3.412 biljaka hrasta lužnjaka i hrasta kitnjaka i to na dva načina. Jedan dio u razmaku sadnje $3 \mathrm{x}$ $3 \mathrm{~m}$ u polipropilenskim štitnicima (slika 2). Drugi dio razmaka sadnje 2 x 2 m uobičajenim načinom (bez štitnika).

Memorijalni dio je smješten u odsjeku $13 \mathrm{~d}$ na površini od 1,64 ha. U tom dijelu posađene su vrste drveća, grmlja i prizemnog rašća koje su specifične za države jugoistočne Europe koje sudjeluju u FOPER II projektu (Albanija, Bosna i Hercegovina, Crna Gora, Finska, Hrvatska, Makedonija i Srbija). Europski šumarski institut (EFI) osnovao je 2004. godine projekt pod naslovom „Obrazovanje i istraživanje iz šumarske politike i ekonomike na području jugo-

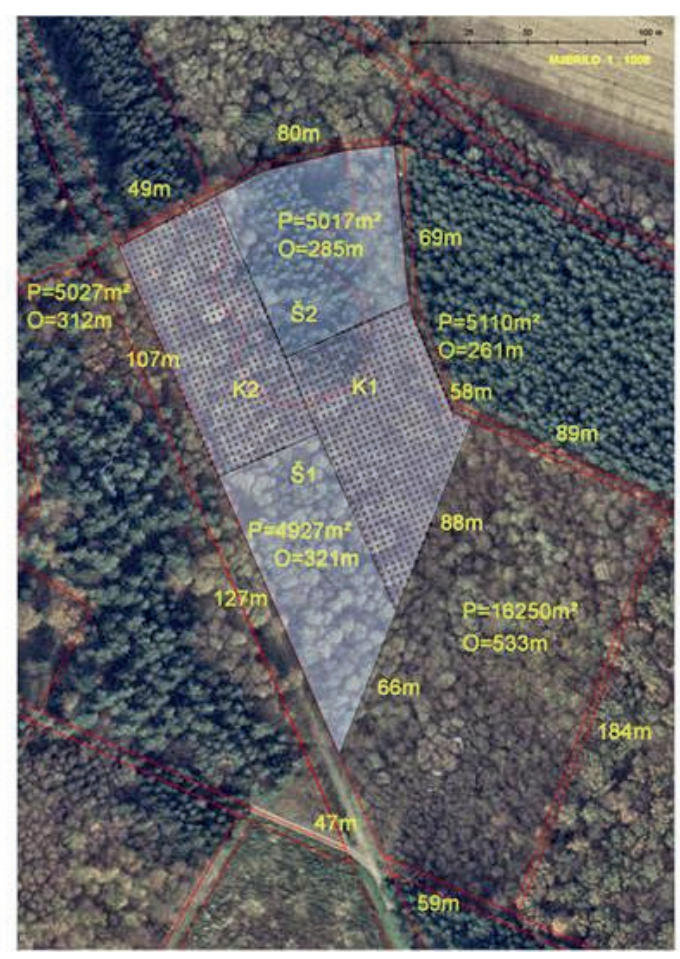

Slika 1. Ortofoto plana pokusa

Figure 1. Orthophoto experimental plan istočne Europe (Forest Policy and Economics Education and Research (FOPER) on the area of South East Europe). Projekt je imao za cilj jačanje kapaciteta obrazovanja, vježbanja i istraživanja iz područja šumarske politike i ekonomike. U projekt je bilo uključeno stotinjak ljudi iz različitih zemalja, koji su kroz svoj rad u istom cilju razvijali međusobna poznanstva i suradnju. Tako se spontano rodila ideja o osnivanju FOPER šume koja će biti reprezentant sinergije obrazovanja, istraživanja i zadovoljstva. S jedne strane istraživački dio će simbolizirati primarne ciljeve projekta, a s druge strane FOPER šume memorijalni dio će sa hortikulturnim uljepšavanjem simbolizirati suradnju i prijateljstvo koje se razvilo tijekom 8 godina (2005. do 2013. godine) između ljudi i zemalja koje su bile uključene u projekt FOPER.

U odsjeku 13c do osnivanja "FOPER šume" (slika 1) bila je umjetno podignuta kultura smreke (Picea excelsa L.) i borovca (Pinus strobus L.) s pojedinačnim stablima bagrema (Robinia pseudoaccacia L.) i jasena (Fraxinus excelsior L.).

$\mathrm{Na}$ tim prvotnim staništima na kojima su sađene pretežito kulture smreke, borovca i bagrema započet je pokus konverzije, prevođenja u viši uzgojni oblik.S obzirom na metode konverzije, radi se o direktnoj konverziji sadnjom sadnica, odnosno kako smo mijenjali i vrstu radi se o supstituciji s tipom konverzije: Sadnja sadnica uz djelomično korištenje štitnika za sadnice. A način izvođenja konverzije je sadnja sadnica uz ograđivanje zaštitnom ogradom.

$\mathrm{U}$ istraživačkom dijelu iskopane su dvije pedološke jame (slika 3), uzeti uzorci za fizikalnu i kemijsku analizu tla te uzeti uzorci za izradu monolitnog profila tla. Pedološki profil je iskopan na starom aluvijalnom nanosu nekadašnjeg djelovanja rijeke Drave. Profil je dubine $180 \mathrm{~cm}$ i u donjem dijelu ispod $1 \mathrm{~m}$ se pojavljuje šljunak u većim količinama. Fiziološki aktivnim $\mathrm{P}\left(\mathrm{P}_{2} \mathrm{O}_{5}\right)$ i $\mathrm{K}\left(\mathrm{K}_{2} \mathrm{O}\right)$ je u površinskom horizontu do $3 \mathrm{~cm}$ srednje opskrbljeno tlo, a dalje do dubine od $1 \mathrm{~m}$ vrlo slabo opskrbljeno. Isto tako dušikom (N\%)

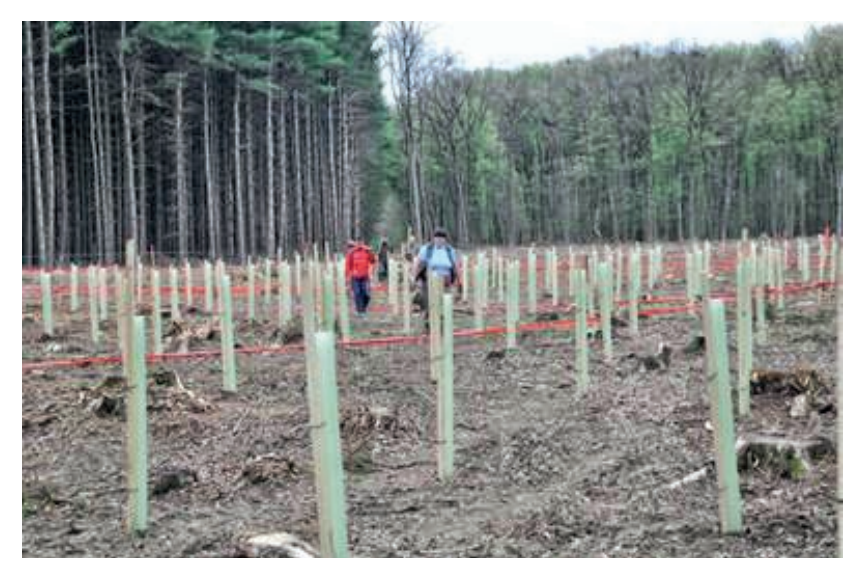

Slika 2. Štitnici na plohi

Figure 2. Tree shelters on plot 


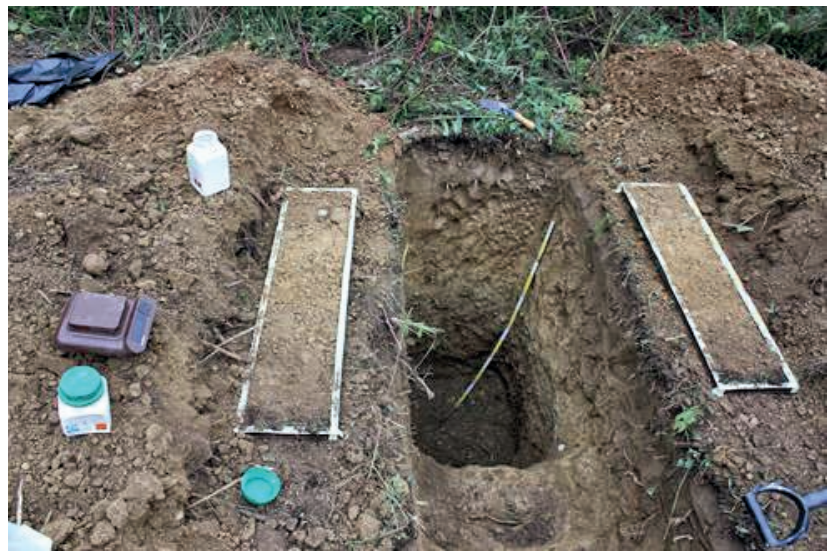

Slika 3. Pedološka istraživanja

Figure 3. Pedological research

je tlo siromašno, jako dobro je do $3 \mathrm{~cm}$ dubine. $U$ površinskim horizontima tlo sadrži dosta humusa (vrlo dobro opskrbljeno). Nemaju povoljan C:N odnos ispod dubine od $30 \mathrm{~cm}$ (mogući izostanak mikrobiološke aktivnosti). Taj odnos trebao bi iznositi od 10 do 15. Po mehaničkome sastavu tlo pripada u lake gline i glinaste ilovače.

Velik dio površina gospodarske jedinice "Zelendvor" zauzimaju umjetno podignute sastojine bjelogorice i crnogorice na staništu hrasta lužnjaka i običnoga graba ((Carpino betuli - Quercetum roboris (Anić 59) Rauš 69)). To su nasadi bagrema (Robinia pseudoaccacia L.), crnog oraha (Juglans nigra L.) i hrasta lužnjaka (Quercus robur L.), koji se počeo unositi u proteklom polurazdoblju, dok od crnogorice raste američki borovac (Pinus strobus L.), obična smreka ( $P i$ cea excelsa L.) i duglazija (Pseudotsuga douglasii L.). U starijim kulturama česte su progale u kojima se nalaze elementi zavičajne vegetacije ((lužnjak (Quercus robur L.), obični grab (Carpinus betulus L.), kupina (Rubus caesius L.), lijeska (Corylus avelana L.), Convalaria majalis L., Pteridium aquilinum L., Carex brizoides L.)). Vrsta koja zauzima veće površine su sastojine bagrema (Robinia pseudoaccacia) razbacane po gospodarskoj jedinici i to na najlošijim stanišnim i sastojinskim prilikama. Za područje cijele gospodarske jedinice ustanovljen je jedan glavni ekološko-gospodarski tip II - G - 10 koji je predstavljen zajednicom hrasta lužnjaka i običnog graba (Carpino betuli - Quercetum roboris (Anić 59) Rauš 69).

Meteorološki podaci dobiveni su od Hrvatskog meteorološkog zavoda za razdoblje od proteklih 40 godina (1979. do 2018. godine). Dinamika visine snijega je ujednačena svih 40 godina, iako se uočavaju pojedini ekstremi visine (1986., 1993. i 2013. godine). Broj snježnih dana je jako varijabilan, od 5 (1989.) do 41 (1996.) dana u godini. Nema značajnijih odstupanja srednje godišnje jačine vjetrova, tek nešto veće vrijednosti 2017. i 2018. godine. U posljednjih 30 godina smanjen je broj dana s maglom na oko 50 . Do značajne promjene je došlo krajem 80 -ih i početkom 90 -ih godina prošloga stoljeća. Najznačajnija odstupanja svih promatranih meteoroloških podataka dogodila su se u vrijednostima temperature zraka. Ona je u 40 godina povišena za $2^{\circ} \mathrm{C}$, što je značajan porast. Promatrajući kretanje temperature zraka u ljetnim mjesecima trend je gotovo isti kao i na godišnjoj razini. Najveći broj kišnih dana uočava se 2014. godine, a najmanji 2011. godine. Najveća godišnja količina oborina evidentirana je 2014. godine, a najmanja 2011. godine.

\section{Terenska istraživanja i obrada podataka - Field research and data processing}

Na površini od 2 ha posađeno je ukupno 3.412 biljaka hrasta lužnjaka i hrasta kitnjaka $(2+1)$ i to na dva razmaka sadnje. Jedan dio u razmaku sadnje 3 x $3 \mathrm{~m}$ u štitnicima (1.107 biljaka). Drugi dio razmaka sadnje 2 x 2 m (2.305 biljaka) uobičajenim načinom (bez štitnika), ali je uz svaku sadnicu zabijen kolčić radi lakšeg uočavanja prilikom njege sadnica. Cijela je površina podijeljena na 24 pod plohe (slika 4) približnih površina. Na jednoj plohi nalazi se jedna vrsta drveća sađena istom načinom. Raspored vrsta je naizmjeničan od plohe do plohe. Upotrijebljen je randomizirani oblik metode, sa 4 bloka i 3 ponavljanja. Oznaka „kultura“ znači da su sadnice u polipropilenskim štitnicima. Oznaka „šuma“ znači da su sadnice bez štitnika. Oznaka „K - K“ znači hrast kitnjak u štitnicima; oznaka „K - L“ znači hrast lužnjak u štitnicima; oznaka „ $\check{S}$ - K“ znači hrast kitnjak bez štitnika; oznaka „ک̌ - L“ znači hrast lužnjak bez štitnika (tablice 1 do 4 ).

Visina biljaka mjerena je svake godine u vrijeme mirovanja vegetacije u razdoblju prema planu (2012. do 2017. godine) i rasporedu mjernim štapom zaokruženo na $5 \mathrm{~cm}$ šest godina uzastopce. Izmjerom 2017. godine mjeren je prsni promjer onih stabala koja su bila viša od $130 \mathrm{~cm}$ promjerkom

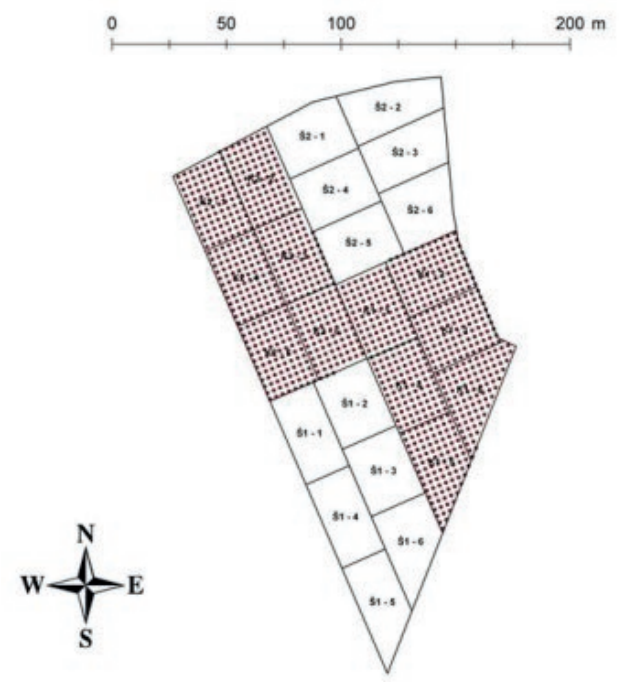

Slika 4. Plan pokusa

Figure 4. Experiment plan 
sa milimetarskom podjelom. Iz odnosa prsnog promjera i visine stabala izračunat je indeks vitkosti. Prisutnost $\mathrm{i}$ intenzitet hrastove pepelnice Microsphaera alphitoides Griff. et Maubl. utvrđivano je tijekom srpnja i kolovoza za razdoblje (2012. do 2014.) od prve tri godine nakon sadnje metodom opažanja i procjene u 6 stupnjeva površinske pokrivenosti lišća ( 0 - bez pepelnice do 5 - preko $80 \%$ pokrivenosti). $\mathrm{Za}$ statističku analizu korišten je Kruskal - Wallis - ov test koji pokazuje postoje li značajne razlike između načina sadnje.

\section{Tumačenje oznaka}

Tablica 1. Osnovna podjela pokusa

Table 1. Basic division of experiments

\begin{tabular}{ccc} 
OZNAKA & RAZMAK SADNJE & ZAŠTITA \\
\hline$K$ & $3 \times 3 \mathrm{~m}$ & štitnik \\
Š & $2 \times 2 \mathrm{~m}$ & bez štitnika
\end{tabular}

Tablica 2. Oznake na karti i na terenu

Table 2. Markings on the map and in the field

$\begin{array}{cccc}\text { OZNAKA } & \text { BLOK } & \text { RAZMAK SADNJE } & \text { ZAŠTITA } \\ \text { K } 1 & 1 . & 3 \times 3 \mathrm{~m} & \text { štitnik } \\ \text { K } 2 & 2 . & 3 \times 3 \mathrm{~m} & \text { štitnik } \\ \text { S } 1 & 1 . & 2 \times 2 \mathrm{~m} & \text { bez štitnika } \\ \text { Š } 2 & 2 . & 2 \times 2 \mathrm{~m} & \text { bez štitnika }\end{array}$

Tablica 3. Oznake u bazi podataka

Table 3. Marking in the database

\begin{tabular}{|cccc}
\hline OZNAKA & VRSTA & RAZMAK SADNJE & ZAŠTITA \\
\hline K - L & lužnjak & $3 \times 3 \mathrm{~m}$ & štitnik \\
K - K & kitnjak & $3 \times 3 \mathrm{~m}$ & štitnik \\
S $-\mathrm{L}$ & lužnjak & $2 \times 2 \mathrm{~m}$ & bez štitnika \\
S - K & kitnjak & $2 \times 2 \mathrm{~m}$ & bez štitnika
\end{tabular}

Tablica 4. Primjeri

Table 4. Examples

$\begin{array}{cc}\text { PRIMJER } & \text { ZNAČENJE } \\ \text { Š } 1-4 & \text { oznaka podplohe } \\ \text { Š } & 2 \times 2 \text { m; bez štitnika } \\ 1 & 1 \text {.blok } \\ 4 & \text { oznaka pod plohe u bloku }(1-6) \\ \text { PRIMJER } & \text { ZNAČENJE } \\ \text { K } 2 \text { - } 5 & \text { oznaka podplohe } \\ \text { K } & 3 \times 3 \text { m; štitnik } \\ 2 & 2 . \text { blok } \\ 5 & \text { oznaka pod plohe u bloku }(1-6)\end{array}$

\section{REZULTATI ISTRAŽIVANJA S RASPRAVOM RESULTS WITH DISCUSSION}

\section{Broj biljaka - Number of trees}

Uspjeh sadnje bio je nešto preko 95\%. Međutim broj biljaka smanjivao se svake godine zbog abiotskih i biotskih čimbenika, usprkos provođenim redovnim mjerama njege.

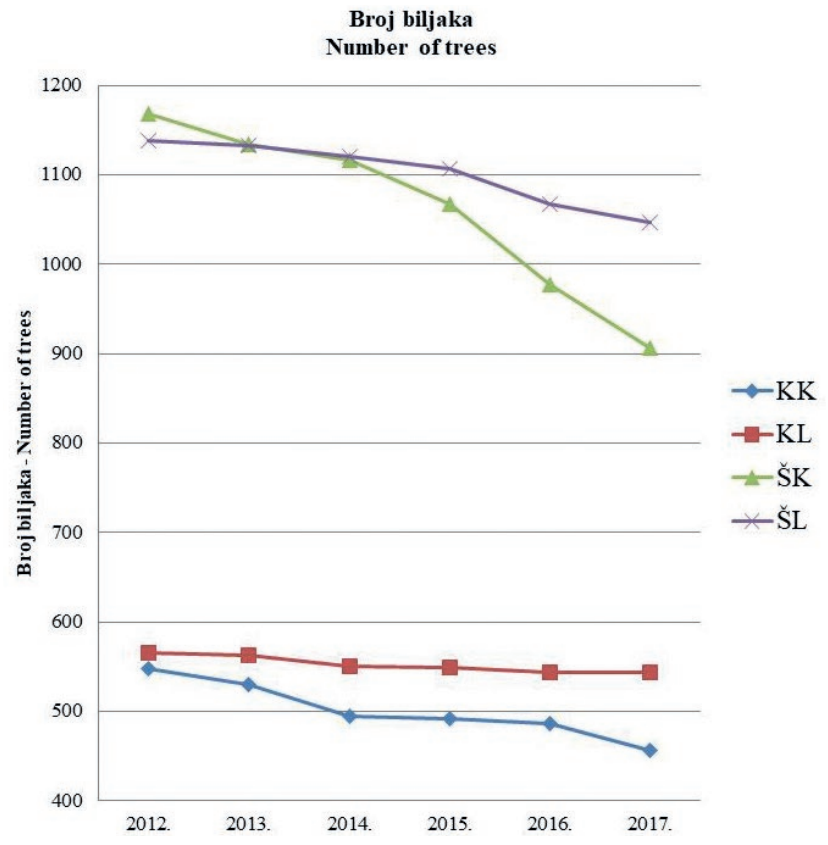

Slika 5. Sveukupan broj biljaka na cijeloj površini

Figure 5. Total number of trees on hall area

Sveukupan broj biljaka i trend preživljenja razvidan je na slici 5. Nakon 5 godina ukupan broj biljaka je 2.955, odnosno došlo je do smanjenja za 14\% (slika 5). Broj biljaka u štitnicima (slika 5) smanjen je za 4\% kod hrasta lužnjaka, a za $17 \%$ kod hrasta kitnjaka. Najveći pad dogodio se tijekom 2014. godine (lužnjak 2\%, kitnjak 7\%). Trend pada nastavljen je kod hrasta kitnjaka, dok se kod hrasta lužnjaka uočava ublažavanje pada. Broj biljaka bez štitnika (slika 5) smanjen je za $8 \%$ kod hrasta lužnjaka, a za $22 \%$ kod hrasta kitnjaka. Trend pada nastavljen je istim intenzitetom kod hrasta kitnjaka, dok se kod hrasta lužnjaka uočava blaži pad. Ukupan broj biljaka hrasta kitnjaka smanjen je 23\% kod sadnica bez štitnika, a 17\% kod sadnica u štitnicima. Dakle, preživljavanje je veće kod sadnica hrasta kitnjaka u štitnicima. Takve rezultate obrazlažu Potter (1991) i Ponder (1996), tvrde da je preživljavanje bolje u štitnicima. Kao i Liović i dr. (2019) tvrde da je preživljavanje biljaka značajno veće u štitnicima nego bez njih te su polipropilenski štitnici uspjeli smanjiti mortalitet sadnica hrasta (Liović 2001).

Ukupan broj biljaka hrasta lužnjaka smanjen je $8 \%$ kod sadnica bez štitnika, a $4 \%$ kod sadnica u štitnicima.

\section{Visine stabala - Tree heights}

Prikazani snop (slika 6) srednjih vrijednosti izmjerenih visina ukazuje na značajne razlike. Visine biljaka u štitnicima su značajno veće bez obzira na vrstu drveća. U 2017. godini razlika iznosi oko $110 \mathrm{~cm}$. Još veća razlika uočava se u 2014. i 2015. godini. Srednja vrijednost hrasta lužnjaka u štitnicima (K - L) iznosi $368,7 \mathrm{~cm}$ u 2017. godini. Sred- 


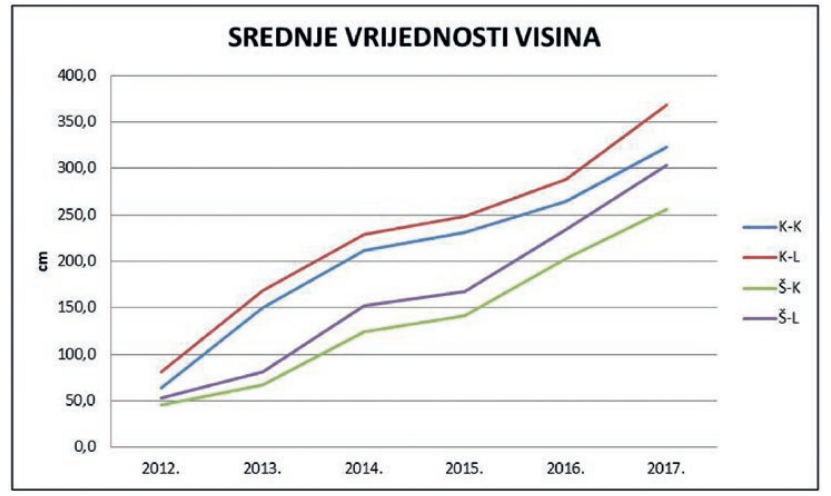

Slika 6. Srednje vrijednosti visina

Figure 6. Tree height mean

nja vrijednost hrasta kitnjaka bez štitnika $(\check{S}-\mathrm{K})$ iznosi $256,1 \mathrm{~cm}$ u 2017. godini. Njihov raspon je oko $110 \mathrm{~cm}$.

Snop izmjerenih visina hrasta kitnjaka u štitnicima ukazuje na sličnost ponašanja, odnosno trenda na svim podplohama. No, $s$ vremenskim odmakom uočava se veća razlika u visinama sadnica između pod ploha. U 2017. godini ta razlika se kreće oko $60 \mathrm{~cm}$. Srednja vrijednost K1-2 pod plohe iznosi $350,6 \mathrm{~cm}$, a maksimalna $460 \mathrm{~cm}$. Srednja vrijednost K2-5 pod plohe iznosi $292,7 \mathrm{~cm}$, a minimalna $200 \mathrm{~cm}$. Raspon najniže i najviše biljke u 2017. godini iznosi $260 \mathrm{~cm}$.

Snop izmjerenih visina hrasta lužnjaka u štitnicima ukazuje na sličnost ponašanja, odnosno trenda na svim pod plohama. No, s vremenskim odmakom uočava se veća razlika u visinama sadnica između pod ploha. U 2017. godini ta razlika se kreće oko $50 \mathrm{~cm}$. Srednja vrijednost K2-2 pod plohe iznosi $384,1 \mathrm{~cm}$, a maksimalna $460 \mathrm{~cm}$. Srednja vrijednost $\mathrm{K} 2-4$ pod plohe iznosi $336,4 \mathrm{~cm}$, a minimalna $240 \mathrm{~cm}$. Raspon najniže i najviše biljke u 2017. godini iznosi $220 \mathrm{~cm}$.

Snop izmjerenih visina hrasta kitnjaka bez štitnika ukazuje na sličnost ponašanja, ali uočenih razlika srednjih vrijednosti među pod plohama. No, s vremenskim odmakom uočava se veća razlika u visinama sadnica između pod ploha. U 2017. godini ta razlika se kreće oko $80 \mathrm{~cm}$. Srednja vrijednost Š1-4 pod plohe iznosi $285,0 \mathrm{~cm}$, a maksimalna $400 \mathrm{~cm}$. Srednja vrijednost $\breve{1} 1-2$ pod plohe iznosi $205,9 \mathrm{~cm}$, a minimalna $105 \mathrm{~cm}$. Raspon najniže i najviše biljke u 2017. godini iznosi $295 \mathrm{~cm}$.

Snop izmjerenih visina hrasta lužnjaka bez štitnika ukazuje na sličnost ponašanja, odnosno trenda na svim pod plohama. No, s vremenskim odmakom uočava se veća razlika u visinama sadnica između pod ploha. U 2017. godini ta razlika se kreće oko $50 \mathrm{~cm}$. Srednja vrijednost $\mathrm{S} 2-6$ pod plohe iznosi $321,6 \mathrm{~cm}$, a maksimalna $450 \mathrm{~cm}$. Srednja vrijednost Š1-5 pod plohe iznosi $276,8 \mathrm{~cm}$, a minimalna $200 \mathrm{~cm}$. Raspon najniže i najviše biljke u 2017. godini iznosi $250 \mathrm{~cm}$.

Usporedba visina stabala hrasta kitnjaka u štitnicima pokazuje da nema značajne razlike među pod plohama. Veći prirast uočava se pri izmjeri 2013. i 2017. godine. Usporedba visina stabala hrasta lužnjaka u štitnicima pokazuje da nema značajne razlike među pod plohama. Veći prirast uočava se pri izmjeri 2013. i 2017. godine. Usporedba visina stabala hrasta kitnjaka bez štitnika pokazuje da postoje značajne razlike među pod plohama i to posebno kod š1-2 i Š1-6 pod ploha. Prirast je dosta ujednačen svih godina. Usporedba visina stabala hrasta lužnjaka bez štitnika pokazuje da postoje značajne razlike među pod plohama i to posebno kod Š1-5 pod plohe. Prirast je dosta ujednačen svih godina. Kod navedenih ploha (Š1-2, Š1-5 i Š1-6) tijekom izmjere uočeno je mjestimično oštećivanje biljaka od divljači. Stabla hrasta kitnjaka rasla u štitnicima i u kasnijoj dobi (5 godina nakon sadnje) nakon što su značajno nadrasla visinu štitnika $(1 \mathrm{~m})$ i dalje postižu veće visine od ostalih stabala koja su rasla bez štitnika. Stabla hrasta lužnjaka rasla u štitnicima i u kasnijoj dobi (5 godina nakon sadnje) nakon što su značajno nadrasla visinu štitnika (1 m) i dalje postižu veće visine od ostalih stabala koja su rasla bez štitnika. U usporedbi s hrastom kitnjakom stabla hrasta lužnjaka značajno su viša.

\section{Prsni promjeri - Diameter breast height}

Prsni promjeri hrasta kitnjaka u štitnicima (slika 7) mjereni 2017. godine značajno su veći od stabala raslih bez štitnika. Prsni promjeri hrasta lužnjaka u štitnicima (slika 7) mjereni 2017. godine su značajno veći od stabala rasla bez štitnika. Ujedno su jačih prsnih promjera od stabala hrasta kitnjaka.

Koeficijent determinacije izjednačenja visina hrasta lužnjaka u štitnicima u usporedbi s prsnim promjerima je relativno visok (70\%) usprkos starosti stabala (8 godina). Koeficijent determinacije izjednačenja visina hrasta kitnjaka bez štitnika u usporedbi s prsnim promjerima je re-

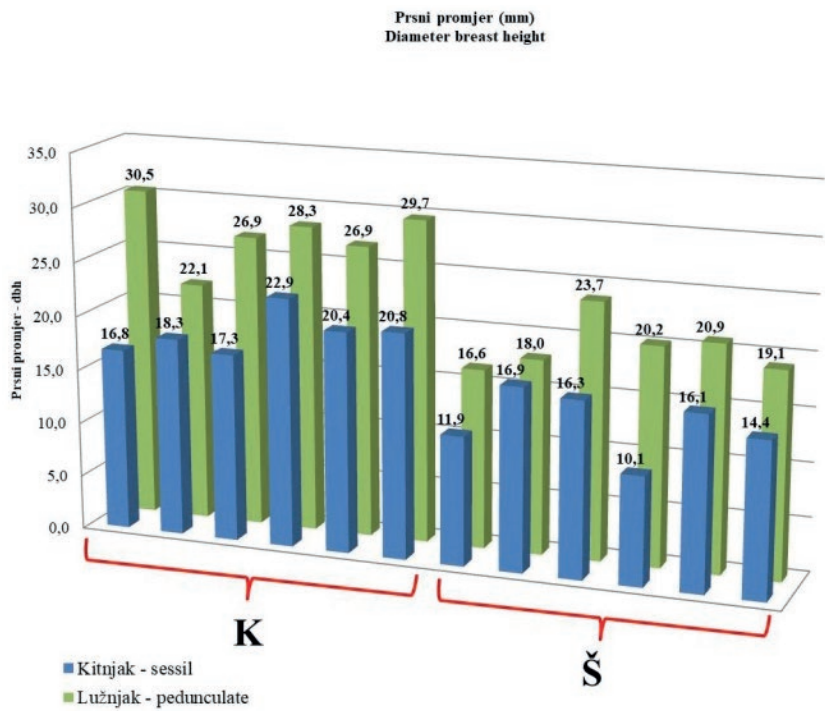

Slika 7. Prsni promjeri po pod plohama

Figure 7. Diameter breast height per subplots 


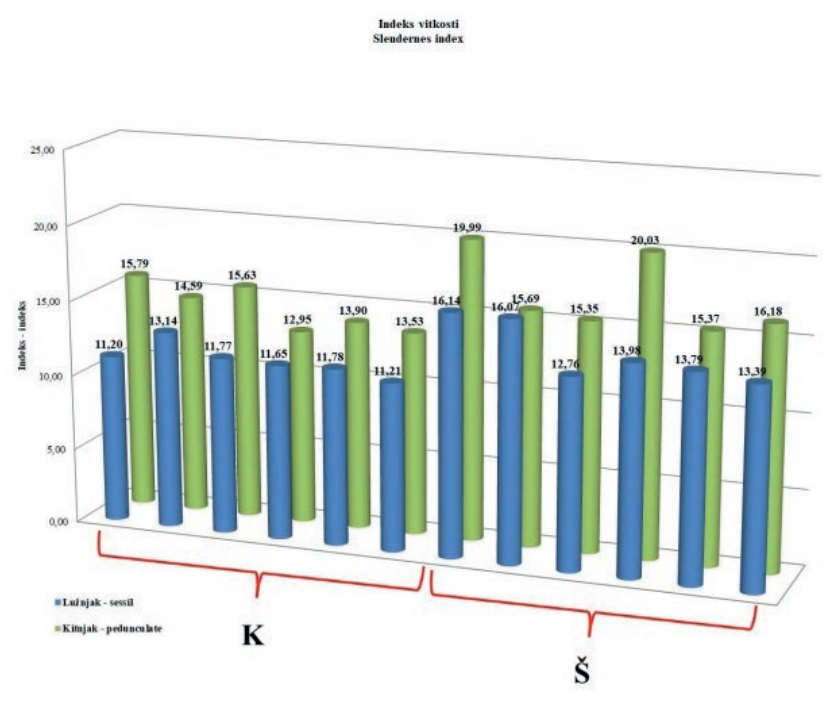

Slika 8. Indeks vitkosti po pod plohama

Figure 8. Slendernes index per subplots

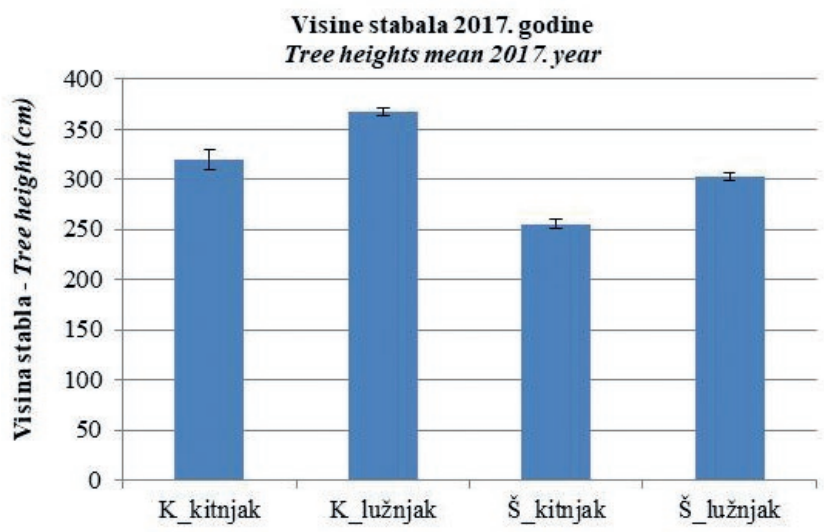

Slika 9. Prosječna vrijednost visina (AV $\pm 1.96 * \mathrm{SE})$ prema različitom načinu sadnje u zadnjoj godini izmjere

Figure 9. Tree heights average value per different method of planting in last measured year

lativno visok (76\%) usprkos starosti stabala (8 godina). Koeficijent determinacije izjednačenja visina hrasta lužnjaka bez štitnika u usporedbi s prsnim promjerima je relativno visok (70\%) usprkos starosti stabala (8 godina).

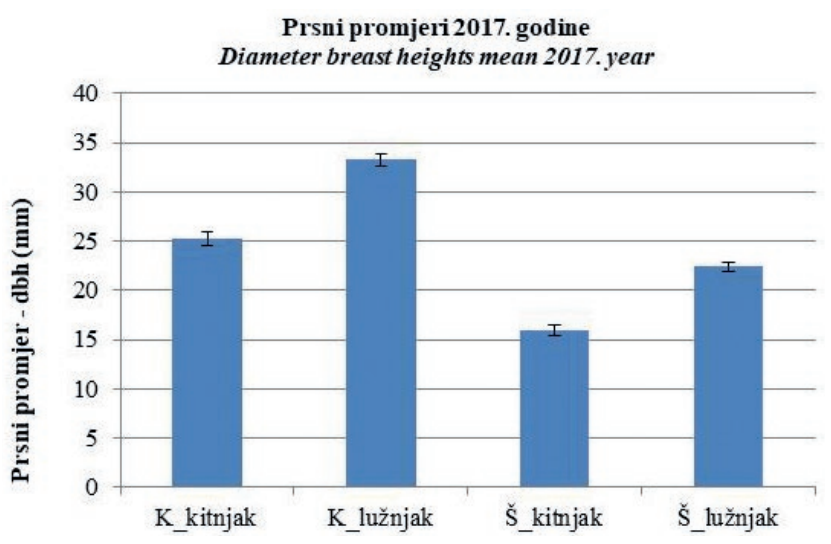

Slika 10. Prosječna vrijednost prsnog promjera stabala (AV $\pm 1.96 * \mathrm{SE}$ ) prema različitom načinu sadnje

Figure 10. Diameter breast height average value per different method of planting

Koeficijent determinacije izjednačenja visina hrasta kitnjaka u štitnicima u usporedbi s prsnim promjerima je relativno visok (79\%) usprkos starosti stabala (8 godina).

Najveće vrijednosti prsnih promjera imaju stabla hrasta kitnjaka bez štitnika u Š2-3 pod plohi. Najmanje u Šs-2 pod plohi. Najveće vrijednosti visina imaju stabla hrasta kitnjaka bez štitnika u Š2-3 pod plohi, koja su ujedno i najdeblja. Najmanje u Š1-2 pod plohi kao i kod prsnih promjera. Najveće vrijednosti prsnih promjera imaju stabla hrasta kitnjaka bez štitnika u Š2-6 pod plohi. Najmanje u Š2-2 pod plohi. Najveće vrijednosti visina imaju stabla hrasta lužnjaka bez štitnika na Š2-6 pod plohi, koja su ujedno i najdeblja. Najmanje na Š1-5 pod plohi.

Indeks vitkosti pokazuje odnos visine i prsnog promjera. Što je indeks manji stabla su manje vitka i otpornija na savijanje. Indeks vitkosti hrasta kitnjaka (slika 8) generalno je manji u štitnicima od onih bez štitnika. Indeks vitkosti hrasta lužnjaka (slika 8) generalno je manji u štitnicima od onih bez štitnika. U usporedbi s hrastom kitnjakom indeks vitkosti oba načina sadnje je manji, a najmanji kod hrasta lužnjaka u štitnicima.

Postoji značajna razlika visina prema načinu sadnje (slika 9).

Tablica 5. Deskripcija po svim ponavljanjima

Table 5. Description per all repetitions

\begin{tabular}{|l|l|r|l|l|r|r|r|r|r|}
\hline sadnja_vrsta & Variable & Obs & Mean & STDEV & Min & Max & $1.96 * S E$ & 95\%Cl up & $95 \%$ Cl down \\
\hline K_kitnjak & h_2017 & 140 & 319,9286 & 59,94898 & 135 & 460 & 9,930563 & 329,8591626 & 309,9980374 \\
\hline K_lužnjak & h_2017 & 181 & 367,8729 & 51,83875 & 220 & 510 & 3,853144 & 371,7260439 & 364,0197561 \\
\hline Š_kitnjak & h_2017 & 227 & 255,3524 & 65,70152 & 105 & 430 & 4,360763 & 259,713163 & 250,991637 \\
\hline Š_lužnjak & h_2017 & 310 & 302,9677 & 64,47748 & 140 & 450 & 3,662075 & 306,6297748 & 299,3056252 \\
\hline K_kitnjak & d_2017 & 140 & 25,27143 & 8,439239 & 4 & 50 & 0,713246 & 25,98467587 & 24,55818413 \\
\hline K_lužnjak & d_2017 & 181 & 33,27624 & 8,639119 & 9 & 60 & 0,642141 & 33,91838066 & 32,63409934 \\
\hline Š_kitnjak & d_2017 & 227 & 15,95154 & 7,884809 & 0 & 42 & 0,523333 & 16,47487315 & 15,42820685 \\
\hline Š_lužnjak & d_2017 & 310 & 22,38387 & 8,519409 & 5 & 55 & 0,48387 & 22,86773992 & 21,90000008 \\
\hline
\end{tabular}


Kruskal - Waliss - ov test (tablica 5) pokazuje da postoje značajne razlike između visina stabala između 4 grupa, $\chi^{2}$ (3) $=245.441, \mathrm{p}<0,05$.

Postoji značajna razlika prsnog promjera prema načinu sadnje (slika 10).

\section{Zahvaćenost hrastovom pepelnicom - Infestation by oak powdery mildew}

Prisutnost hrastove pepelnice na lišću i njezin intenzitet promatran je i evidentiran tijekom tri godine (2012. do 2014.). Dinamika razvoja pepelnice (slika 11) na stablima hrasta kitnjaka u štitnicima prati Gaussovu krivulju s pomakom prema vremenskom odmaku. Samo što u 2012. godini nalikuje na Liocourtovu krivulju. U prvoj godini pepelnica se na hrastu kitnjaku u štitnicima još nije pojavila na preko polovice broja biljaka (57\%). U drugoj godini pepelnica se na hrastu kitnjaku u štitnicima razvila na preko tri četvrtine broja biljaka (78\%) do $40 \%$ pokrivenosti lišća. U trećoj godini pepelnica je prisutna na hrastu kitnjaku u štitnicima na svim biljkama. Na preko $50 \%$ biljaka prisutna je na 40 do $80 \%$ površine lišća. U prvoj godini pepelnica se na hrastu lužnjaku u štitnicima još nije pojavila na preko dvije trećine broja biljaka (68\%). U dru-
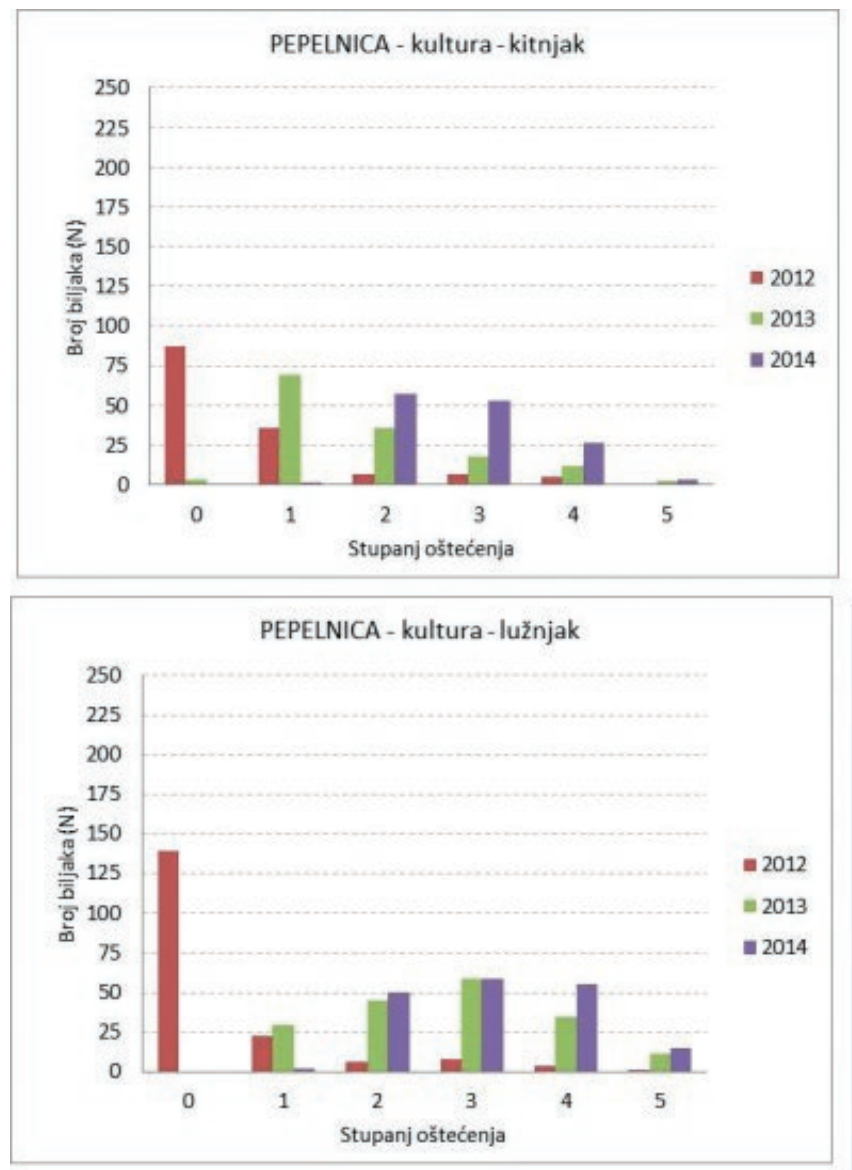

goj godini pepelnica se na hrastu lužnjaku u štitnicima razvila na $41 \%$ broja biljaka do $40 \%$ pokrivenosti lišća. U trećoj godini pepelnica je prisutna na hrastu lužnjaku u štitnicima na svim biljkama. Na preko dvije trećine biljaka prisutna je na 40 do $80 \%$ površine lišća.

Dinamika razvoja pepelnice (slika 11) na stablima hrasta lužnjaka u štitnicima prati Gaussovu krivulju s pomakom prema vremenskom odmaku. Samo što je u 2013. i 2014. godini ona niža i spljoštenija. U prvoj godini nešto je veći postotak broja biljaka hrasta lužnjaka bez prisutnosti pepelnice u odnosu na hrast kitnjak u štitnicima. U drugoj godini hrast kitnjak u štitnicima otporniji je na prisutnost pepelnice od hrasta lužnjaka. U trećoj godini prisutnost pepelnice je podjednako kod obje vrste u štitnicima uz manje razlike u intenzitetu pokrivenosti lišća. U prvoj godini pepelnica se na hrastu kitnjaku bez štitnika pojavila na skoro svim biljkama (92\%). Na $60 \%$ broja biljaka prisutna je do $40 \%$ površine lišća. $U$ drugoj godini pepelnica se na hrastu kitnjaku bez štitnika razvila na više od polovice broja biljaka (56\%) do 20\% pokrivenosti lišća. U trećoj godini pepelnica je prisutna na hrastu kitnjaku bez štitnika na svim biljkama. Na skoro dvije trećine (63\%) biljaka prisutna je na 40 do $80 \%$ površine lišća.
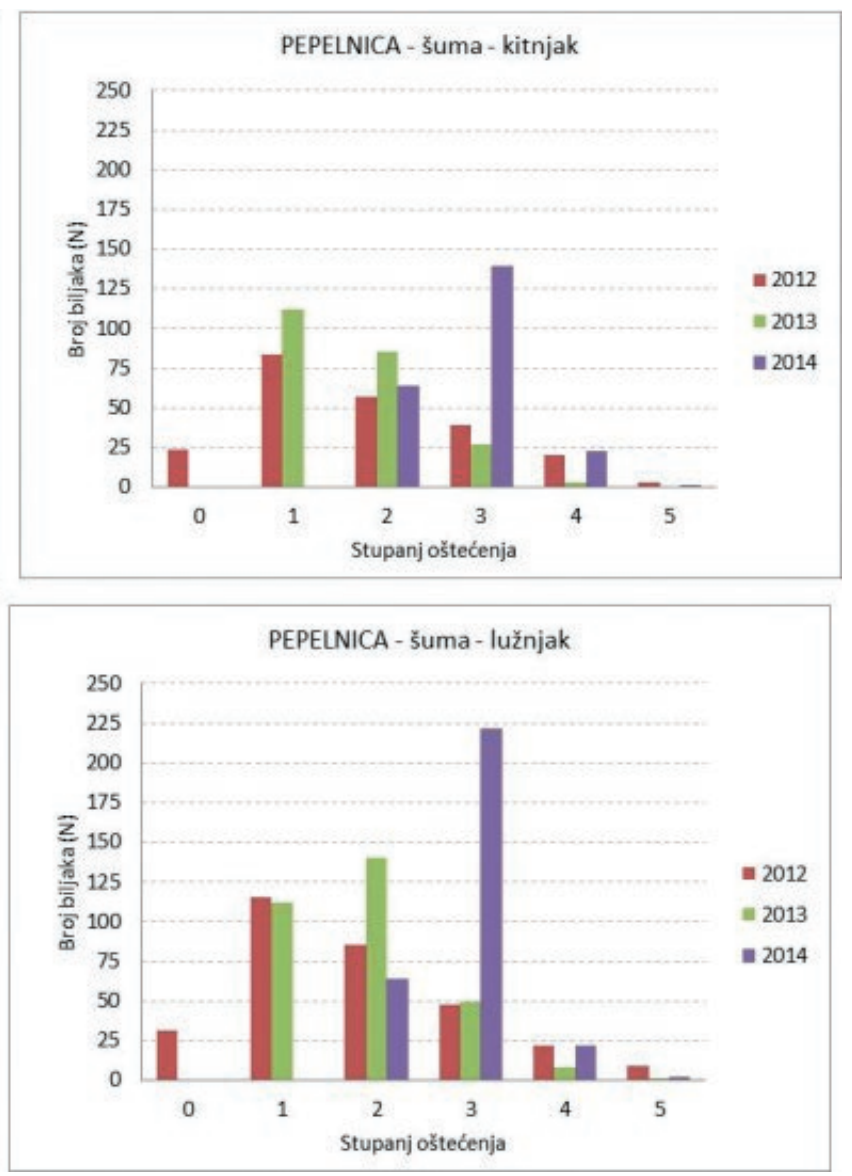

Slika 11. Broj biljaka po stupnjevima oštećenja i godinama promatranja Figure 11. Number of plants by degrees of damage and years of observations 

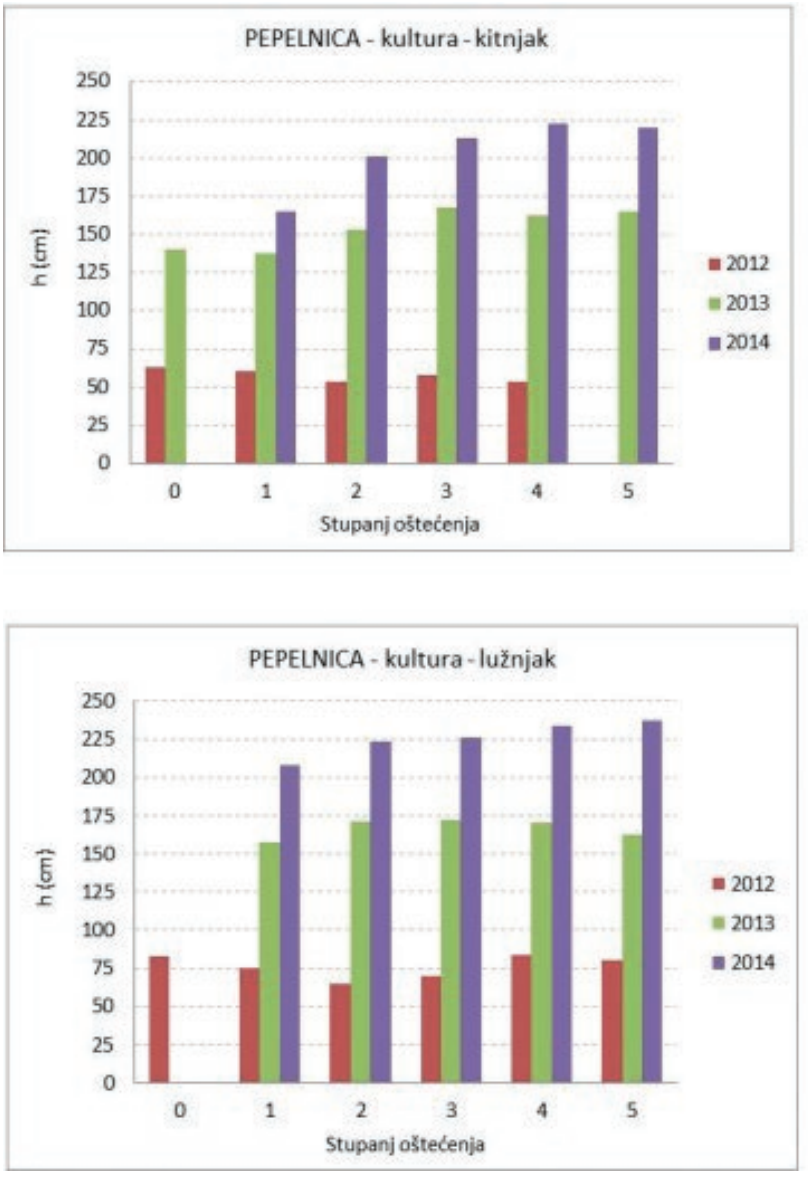

Slika 12. Visine stabala po stupnjevima oštećenja

Figure 12. Tree heights by degrees of damage

Dinamika razvoja pepelnice (slika 11) na stablima hrasta kitnjaka bez štitnika prati Gaussovu krivulju s pomakom prema vremenskom odmaku. Samo što je u 2014. godini ona uža i strmija. U prvoj godini pepelnica se na hrastu lužnjaku bez štitnika pojavila na skoro svim biljkama (89\%). Na polovini broja biljaka (51\%) prisutnost pepelnice je preko $40 \%$ površine lišća. U drugoj godini sva su stabla zaražena. Pepelnica se na hrastu lužnjaku bez štitnika razvila na $62 \%$ broja biljaka preko $20 \%$ pokrivenosti lišća. U trećoj godini pepelnica je prisutna na hrastu kitnjaku bez štitnika na svim biljkama. Na skoro dvije trećine (65\%) biljaka prisutna je na 40 do $60 \%$ površine lišća. Liović i dr. (2019) su uočili da su zbog napada pepelnice gotovo sve biljke bile njome pokrivene na dijelu krošanja iznad visine štitnika, dok su unutar štitnika biljke izgledale slabije ili uopće nije bilo pepelnice.

Raspodjela pepelnice (slika 8) prema stupnjevima oštećenosti na stablima hrasta lužnjaka bez štitnika prati Gaussovu krivulju s pomakom prema vremenskom odmaku. Samo što je u 2014. godini ona uža i strmija. U prvoj godini veći broj biljaka hrasta lužnjaka bez štitnika ima slabo prisutnost pepelnice (do $20 \%$ pokrivenosti lišća) nego hrasta kitnjaka. Hrast kitnjak je slabije otporan pa je prisutnost veće nego kod hrasta lužnjaka jačih intenziteta. U drugoj
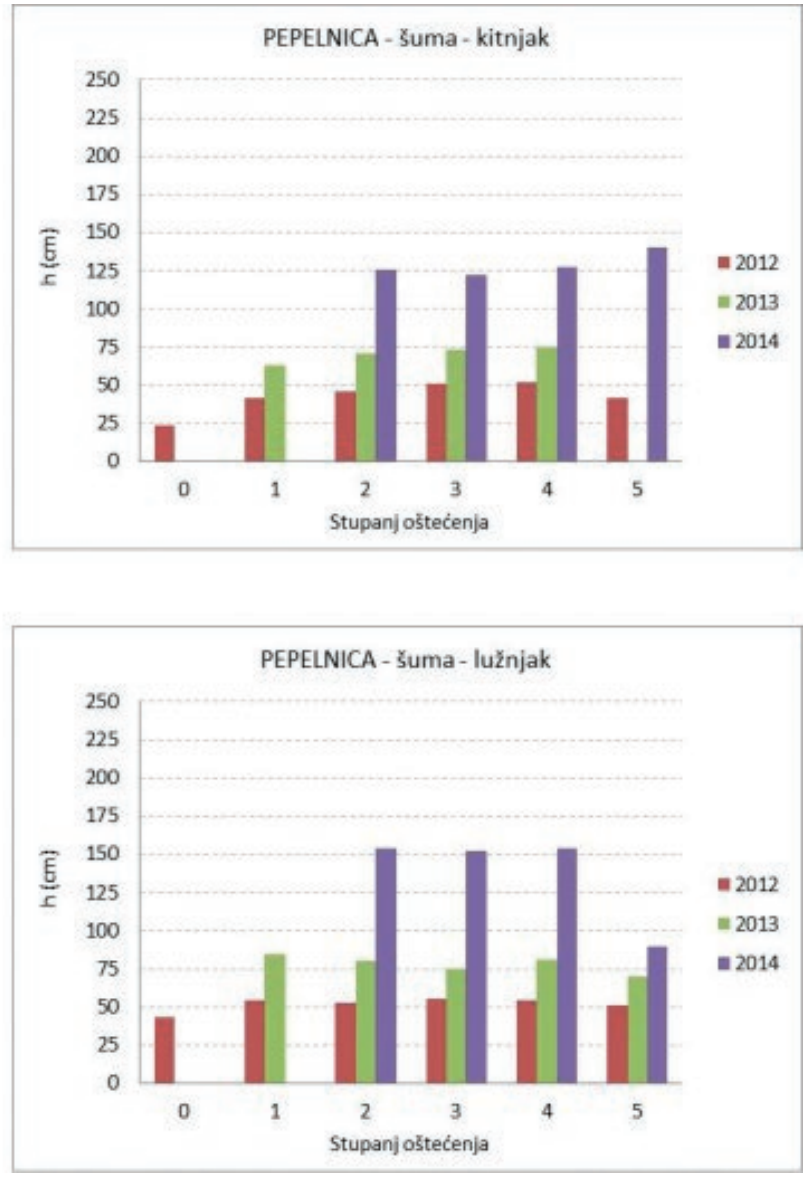

godini hrast lužnjak bez štitnika je značajno osjetljiviji na prisutnost pepelnice nego kitnjak. U trećoj godini prisutnost pepelnice je podjednako kod obje vrste bez štitnika uz manje razlike $\mathrm{u}$ intenzitetu pokrivenosti lišća.

U prvoj godini stabla hrasta kitnjaka i lužnjaka bez štitnika su jače zaražena nego ona u štitnicima. U drugoj godini stabla hrasta kitnjaka bez štitnika su jače zaražena nego stabla u štitnicima. U drugoj su godini stabla hrasta lužnjaka podjednako zaražena bez obzira na način sadnje, ali je kod stabala u štitnicima podjednak raspored stupnjeva oštećenja. U trećoj godini najveće je učešće zaraženih stabala hrasta kitnjaka između 20 i $60 \%$ pokrivenosti pepelnicom lišća kod oba načina sadnje. U trećoj godini prisutnost pepelnice je najizraženije na stablima hrasta lužnjaka bez štitnika i pokrivenosti 40 do $60 \%$ lišća.

Najveća je prisutnost pepelnice stabala bez štitnika u trećoj godini (slika 11), ali samo do $60 \%$ pokrivenosti lišća.

Nije utvrđena korelacija između visine stabala i prisutnosti pepelnice (slika 12).

Za razliku od istraživanja Kirinčića (2016) i Liovića (2001) izračunati visinski prirast stabala u štitnicima je manji 2014. u odnosu na 2013. godinu, dok je te iste godine veći na stablima bez štitnika (slika 13) u odnosu na 2013. godinu. 

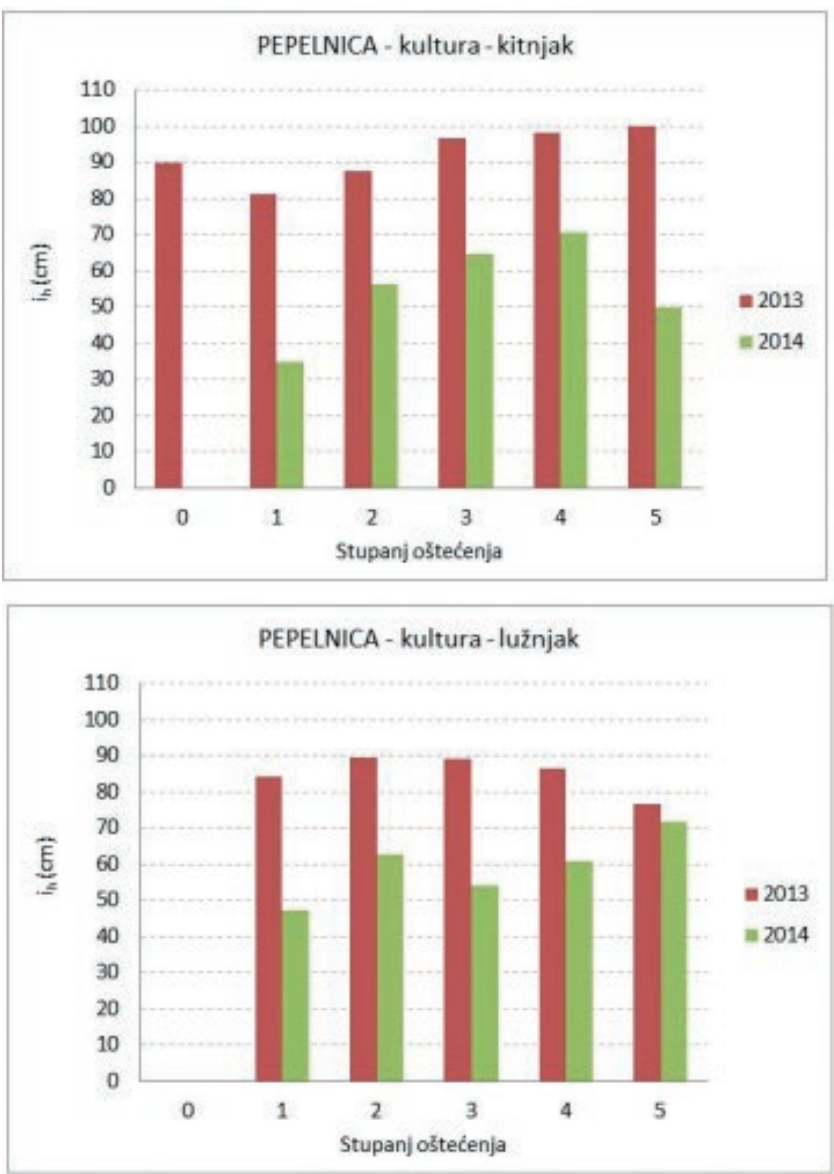

Slika 13. Visinski prirast po stupnjevima oštećenja

Figure 13. Tree height increment by degrees of damage

\section{ZAKLJUČCI}

\section{CONCLUSIONS}

Broj biljaka nakon 5 godina izmjere smanjen je za 14\%. Kod hrasta lužnjaka smanjen je za 4 do 8\%, a kod hrasta kitnjaka za 17 do $22 \%$. Visine i prsni promjeri stabala u štitnicima značajno su veći bez obzira na vrstu drveća. Visine i prsni promjeri hrasta lužnjaka značajno su veće od hrasta kitnjaka. Indeks vitkosti najmanji je kod stabala hrasta lužnjaka u štitnicima. Dakle stabla su „zdepastija“ i otpornija na savijanje. Hrastova pepelnica je jednako zastupljena kod obje vrste drveća i načina sadnje. U štitnicima se pojavljuje kasnije u drugoj godini, ali su zastupljeni svi stupnjevi pokrivenosti lišća. Nije utvrđena korelacija između visina stabala i prisutnosti pepelnice.

\section{ZAHVALA}

\section{ANKNOWLENGMENT}

Posebnu zahvalu upućujem Hrvatskim šumama, njihovoj Upravi šuma Koprivnica, Šumariji Varaždin, koji su prihvatili ideju osnivanja „FOPER ŠUME“ sa svrhom istraživanja rasta i razvoja različitih vrsta i načina sadnje.
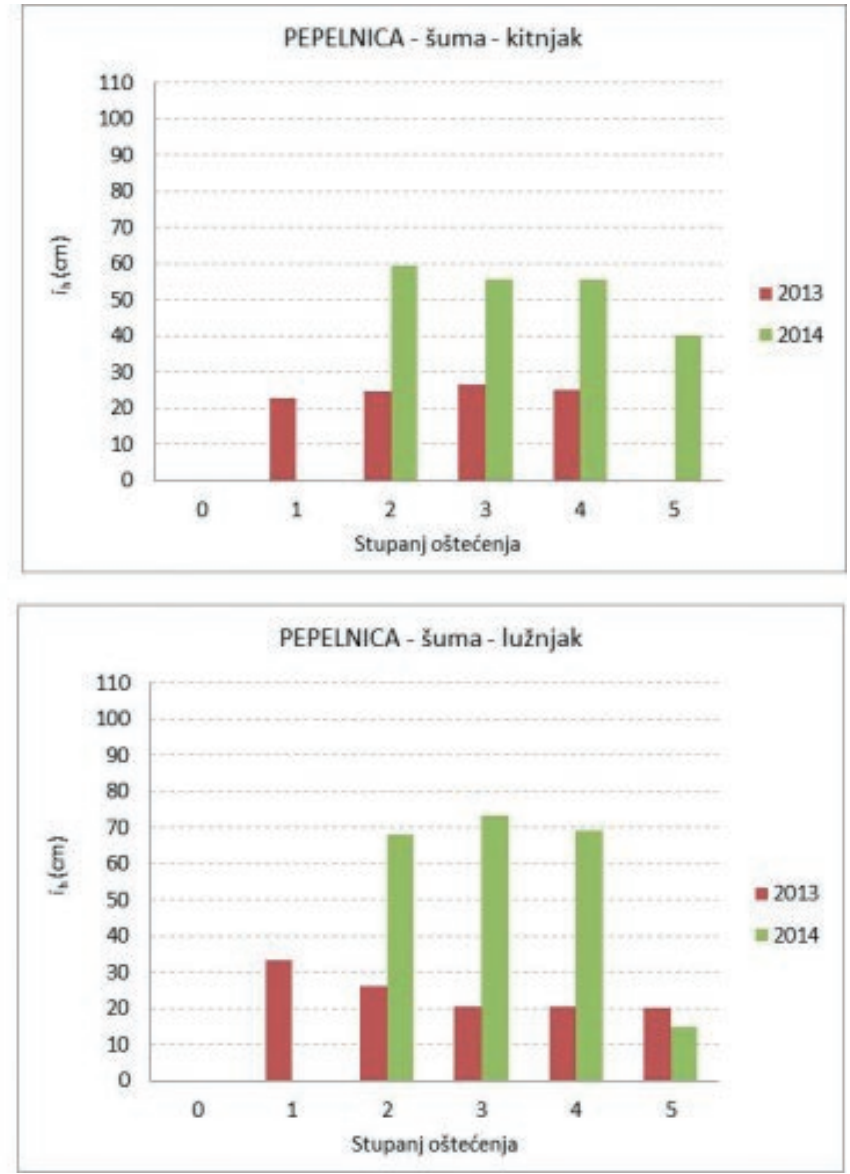

Zahvaljujem svim kolegama na nesebičnom trudu i pomaganju tijekom cijelog razdoblja istraživanja i to: $\mathrm{dr}$. sc. Daliboru Štorgi, mr. sc. Đuri Jendrijevu, Mr. sc. Mirku Kovačevu, mr. sc. Mirjani Grahovac Tremski, Ivanu Krašeku dipl. ing. šum., Zvonku Kranjcu dipl. ing. šum., Davoru Topolnjaku, dipl. ing. šum., Vedranu Križancu, kao i svim radnicima šumarije Varaždin, koji su u različitim fazama radili na osnivanju pokusne plohe i provođenoj izmjeri.

Posebno se zahvaljujem Nataši Lovrić dipl. ing. šum. I mr. sc. Marku Lovriću, kao i svim djelatnicima Hrvatskog šumarskog instituta koji su svojim savjetima i uputama pomogli u kreiranju tijeka istraživanja dr. sc. Sanji Perić, dr. sc. Borisu Vrbeku, dr. sc. Nenadu Potočiću, dr. sc. Ivanu Seletkoviću, mr. sc. Borisu Lioviću, dr. sc. Tomislavu Dubravcu, dr. sc. Krunoslavu Indiru, dr. sc. Dijani Vuletić, dr. sc. Maši Zorani Ostrogović Sever.

Veliko hvala prof. dr. sc. Margaret Shanon, koordinatorici međunarodnog projekta „FOPER“ na svesrdnoj podršci prilikom osnivanja ovih istraživanja.

Na kraju zahvaljujem mladim kolegama koji su svesrdno pomagali pri izmjeri mr. sc. Miljenku Županiću, Goranu Habušu, dipl. ing. šum., Svijetlani Borak mag. ing. silv., Ivici 
Mikuleku mag. ing. silv., Antunu Viličiću mag. ing. silv., Lari Milošić mag. ing. silv., Nikolini Medenjak Đođ mag. ing. silv.

\section{LITERATURA}

\section{REFERENCES}

Benko, M., M. Curman, S. Danon, 2012.: Does „FOPER“ has its own forest?, SEEFOR 4, str. 61-66, Jastrebarsko

Benko, M., M. Županić, N. Đođ, K. Indir, 2013.: FOPER FOREST, 20th Annual Conference of EFI, , 23. - 27. 09. 2013., Nancy

Dubravac, T., M. Turk, D. Barčić, 2018: Konverzija panjača hrasta crnike (Quercus ilex L.) oplodnim sječama-rezultati višegodišnjih znanstvenih istraživanja. Zbornik radova: Poljoprivreda i šumarstvo na kršu mediteransko-sub mediteranskog istočno jadranskog područja-stanje i perspektive. Posebna izdanja, Knjiga 27 , Urednici, Šarić, T., V. Beus,, str: 103-121., Sarajevo

Dubravac, T., S. Dekanić, 2011: Oplodnim sječama od panjače do sjemenjače hrasta crnike (Quercus ilex L.) - Rezultati višegodišnjeg praćenja obnove, rasta i razvoja mlade sjemenjače hrasta crnike na stalnoj pokusnoj plohi u Puli. Hrvatska akademija znanosti i umjetnosti, Znanstveno vijeće za poljoprivredu i šumarstvo, Znanstveno vijeće za zaštitu prirode. Znanstveni skup: Šumarstvo i poljoprivreda hrvatskog sredozemlja na pragu Europske unije, 13.14.10.2011., Sažeci, str. 20-21., Split

Dubravac, T., V. Krejči 2001: Pojavnost mladog naraštaja u sačuvanim panjačama hrasta crnike (Quercus ilex L.) - uvjet osiguranja budućih sjemenjača. Znanstvena knjiga: Znanost u potrajnom gospodarenju hrvatskim šumama, Šumarski fakultet Sveučilišta u Zagrebu, Šumarski institut Jastrebarsko, "Hrvatske šume" d.o.o. pp: 43-52, Zagreb

Kirinčić, M., 2016.; Zaštita šuma pomoću tullyjevih cijevi na prostoru šumarije Pisarovina, završni rad, Veleučilište u Karlovcu, Karlovac

Krejči, V., T. Dubravac, 2000: Obnova panjača hrasta crnike (Quercus ilex L.) oplodnom sječom. Šum. list 11-12: 661668, Zagreb
Krejči, V., T. Dubravac, 2004: Oplodnom sječom od panjače do sjemenjače hrasta crnike (Quercus ilex L.) Šum. list 7-8: 405-412, Zagreb

Liović, B. 1996: „Zaštita šumskog drveća polipropilenskim štitnicima" ,Glasilo Šumarskog instituta Jastrebarsko, Radovi, Volumen 28, Broj 1-2, Jastrebarsko

Liović, B., 1991: Primjena plastičnih štitnika za zaštitu sadnica hrasta. (The application of plastic treeshelters for the protection of oak seedlings). Rad. Šumar. inst. 26(1): 129134, Zagreb.

Liović, B., 1993: Zaštita sadnica šumskog drveća polipropilenskim štitnicima. (Protection of forest tree seedlings by polypropylene shelters). Rad. Šumar. inst. 28(1/2): 255-262, Jastrebarsko.

Liović, B., 1996: „Nizinske šume Pokupskog bazena“, Glasilo Šumarskog instituta, Jastrebarsko, Radovi, Volumen 31, Broj 1-2, Jastrebarsko

Liović, B., 2001: Rezultati primjene polipropilenskih štitnika za zaštitu sadnica hrasta lužnjaka - 6 godišnji pokus. Znanstvena knjiga: Znanost u potrajnom gospodarenju hrvatskim šumama., 2000. 309-317., Zagreb

Liović, B., 2001: Rezultati primjene polipropilenskih štitnika za zaštitu sadnica hrasta lužnjaka - 6 godišnji pokus // Znanost u potrajnom gospodarenju hrvatskim šumama / Matić, S., A. P. B. Krpan, J. Gračan, (ur.). Zagreb: Šumarski fakultet; Šumarski institut, Zagreb

Liović, B., Ž. Tomašić, T. Dubravac, R. Licht, M. Turk, 2019: The Effect of Polypropylene Tree Shelters on Growth and Survival of Pedunculate Oak Seedlings (Quercus robur L.) // South-east European forestry, 10, 1; 89-96:10.15177/SEEFOR.19-07, Jastrebarsko

Mayhead, G. J., I. R. Boothman 1997. The effect of treeshelter height on the early growth of sessile oak (Quercus petraea (Matt.) Liebl.), Forestry, Vol. 70, No. 2, 151 - 155

Ponder, F. 1996 Tree shelter effects on stem and root biomass of planted hardwoods. In Proceedings of the treeshelter conference, 1995. PA, USA, 19-23., Harrisburg,

Potter, M.J., 1991: Treeshelters. Forestry Commission Handbook No 7. HMSO, London.

\section{SUMIMARY}

The research was carried out in the lowland region at a distance of about $3 \mathrm{~km}$ from the Drava River at an altitude of $190 \mathrm{~m}$, in an area where mostly spruce, white pine and black locust are planted, although the habitat is suitable for planting and growing oak. Considering the changed ecological and climatological conditions, an experimental plot of 2.00 ha was established. Three-year-old $(2+1)$ seedlings of pedunculate oak (Quercus robur) and sessile oak (Quercus petraea) were planted on the plot according to two different methods. The first group was planted at a distance of $3 \times 3 \mathrm{~m}$ in polypropylene shelters. The second group was planted at a distance of $2 \times 2 \mathrm{~m}$ in the regular way (without the shelters). The entire area was divided into 24 plots of approximately the same size. Each plot con- 
tained only one tree species. The arrangement of species alternated between the plots. A randomized block design was used, with 4 blocks and 3 replicates. Tree heights were measured for 5 consecutive years not during the growing season. Breast height diameters were measured at the end of the observed period. The impact and intensity of powdery mildew has been observed for three years during the summer months. The aim of the research is to study the growth and development of pedunculate oak and sessile oak seedlings in an area where these species were not commonly grown, although there are adequate ecological and economic conditions. After 5 years of measurement, the number of plants was reduced by $14 \%$. In pedunculate oak the number of trees was reduced by 4 to $8 \%$, and in sessile oak by 17 to $22 \%$. The height and breast height diameters of the trees grown within the shelters were significantly higher regardless of the tree species. The height and breast height diameter of pedunculate oak trees was significantly larger than of sessile oak trees. No correlation was found between tree height and the presence of powdery mildew.

KEY WORDS: conversion, growth, polyproyilene tree shelters, tree heights, FOPER forest, Zelendvor, pedunculate oak, sessile oak

\section{PRIJE STO GODINA: ŠUMARSKI LIST 9/1920 I 10/1920}

\section{Prodaja ploda od borovice ili venje} (Juniperus communis).

Kod šumske Uprave u Deliblatu (Banat) dana 15. oktobra 1920. u 10 sati prije podne prodavati će se putem javne licitacije uz zatvorene pismene ponude oko 80 (osamdeset) metričkih centi ploda od borovice ili venje (Juniperus communis) veoma dobre kakvoće uz početnu (iskličnu) cijenu od 280 (dvijestoosamdeset) kruna po metričkom centu.

Propisno biljegovane pismene ponude treba predati najkasnije do 14. oktobra 1920. u 12 sati o podne kod Šumske Uprave u Deliblatu.

Ponudi treba priložiti priznanicu, da je kod blagajne Sumske Uprave u Deliblatu ili bilo kod koje državne blagajne kraljevine Srba, Hrvata i Slovenaca položeno 2240 kruna žaobine. U ponudi mora biti izričito navedeno, da su nudiocn uslovi licitacije poznati i da ih bezuslovno prihvacia.

Pobliži uslovi licitacije, obrazac ponude $\mathrm{i}$ napis na omot ponude mogu se pogledati kod Sumske Uprave u Deliblatu, a na zahtjev i poštom poslati.

Prodaja se dogadja postavno u željeznička kola na želježničkoj stanici Jasenova (blizu Bele Crkve), dočim o potrebnim vrećama i materijalu za vezanje ima se kupac o svom trošku pobrinuti.

$1 z$ kancelarije Śumske Uprave u Deliblatu broj 793/920. 